venous injection of agonists or antagonists of $\boldsymbol{\alpha}$-adrenoceptor subtypes in anesthetized openchest dogs.

For this purpose, total spinal anesthesia was performed and mean arterial pressure was maintained at about $80 \mathrm{mmHg}$ by continuous intravenous infusion of epinephrine. The measurement of MCP was made before and after intravenous injection of phenylephrine (PHE, $10 \mu \mathrm{q} / \mathrm{Kg},\left(x_{1}\right.$-agonist), prazosin (PRA, I $50 \mu \mathrm{g} / \mathrm{Kg}, x_{1}-$ antagonist), BHT 920 (BHT, $5 \mu \mathrm{g} / \mathrm{Kg}$, $\alpha_{2}$-agonist) or yohimbine ( $\mathrm{YOH}, 30 \mu \mathrm{g} / \mathrm{Kg}, \alpha_{2}-$ antagonist), in one minute, and the response of MCP to these agonists and antagonists were obtained.

1) PHE ( $\alpha_{1}$-agonist) increased MCP from $10.0 \pm 0.4$ $\mathrm{mmHg}$ (mean $\pm \mathrm{SE}$ ) to $10.9 \pm 0.4 \mathrm{mmHg}(\mathrm{N}=6)$

2) PRA ( $\alpha_{1}$-antagonist) decreased MCP from $10.0 \pm 0.5$ mmHg to $8.5 \pm 0.7 \mathrm{mmHg}(\mathrm{N}=5)$.

3) After pretreatment with PRA( $\alpha_{1}$-antagonist), MCP increasing action of PHE( $\alpha_{1}$-agonist) was blocked. MCP before pretreatment with PRA was $9.3 \pm 0.4$ $\mathrm{mmHg}$ and MCP after $\mathrm{PRA}+\mathrm{PHE}$ was $7.7 \pm 0.3 \mathrm{mmHg}(\mathrm{N}=5)$. 4) $\mathrm{BHT}\left(\alpha_{2}\right.$-agonist) increased MCP from $9.0 \pm 0.3 \mathrm{mmHg}$ to $10.1 \pm 0.3 \mathrm{mmHg}(\mathrm{N}=6)$.

5) YOH( $\alpha_{2}$-antagonist) decreased MCP from $9.8 \pm 0.2$ $\mathrm{mmHg}$ to $7.7 \pm 0.3 \mathrm{mmHg}(\mathrm{N}=5)$.

6) Pretreatment with YOH( $\alpha_{2}$-antagonist) caused MCP increasing action of BHT( $\alpha_{2}$-agonist) to be eliminated.MCP before YOH was $9.6 \pm 0.4 \mathrm{mmHg}$ and $M C P$ after $\mathrm{YOH}+\mathrm{BHT}$ was $8.3 \pm 0.5 \mathrm{mmHg}(\mathrm{N}=5)$.

It is thus suggested that $\alpha_{1}$-adrenoceptor subtype is present in the systemic capacitance vessels (results 1,2 and 3 ) and $\alpha_{2}$-adrenoceptor subtype is also present in the systemic capacitance vessels (results 4,5 and 6 ). Furthermore it is suggested that both $\boldsymbol{\alpha}_{1}$-and $\alpha_{2}$-adrenoceptor are acting in the direction of constricting the systemic capacitance vessels.

$-127-$

\section{CHARACTERISTICS OF CORONARY} ADRENOCEPTORS

Junji Nishimura, Hideo Kanaide and Motoomi Nakamura.

Research Institute of Angiocardiology and Cardiovascular Clinic, Kyushu University

The characteristics of the porcine coronary adrenoceptors were investigated and compared with those of the porcine aorta. $\left[{ }^{3} \mathrm{H}\right](-)$ dihydro-

alprenolol ([ $\left.{ }^{3} \mathrm{H}\right]$ DHA) and $\left[{ }^{3} \mathrm{H}\right]$ prazosin binding to sarcolemmal fractions from porcine coronary artery(CA) and aorta(AO) were used. In the binding isotherms, there were no major differences in the $\mathrm{Kd}$ values of these two radioligands between $\mathrm{CA}$ and $\mathrm{AO}$. However, the Bmax values of $\left[{ }^{3} \mathrm{H}\right] \mathrm{DHA}$ for $\mathrm{CA}$ and $\mathrm{AO}$ were 258 and $37 \mathrm{fmol} / \mathrm{mg}$ protein, respectively and those of $\left[{ }^{3} \mathrm{H}\right]$ prazosin were 12 and $525 \mathrm{fmol} / \mathrm{mg}$ protein, respectively. $B$-Adrenergic agonists competed with $\left[{ }^{3} \mathrm{H}\right] \mathrm{DHA}$ binding sites in $\mathrm{CA}$, with the order of potency of (-)isoproterenol(IP) $>$ (-) norepinephrine (NE) $>$ $(-)$ epinephrine $(E P)>(+) I P$. In case of $A O$, the potency order was $(-) \mathrm{IP}>(-) \mathrm{EP}>(-) \mathrm{NE}$. The $\mathrm{Ki}$ value of $( \pm)$ bisoprolol, a highly $\beta$ l-selective antagonist, for coronary $\beta$-receptors (35 nM) was 56 times lower than that for $A O(2000 \mathrm{nM})$. From these results, we concluded that; 1) $\alpha 1-$ and $\beta-$ adrenoceptors are present in porcine vascular smooth muscle cells, 2) B-receptors of CA are predominantly of the $B 1-t y p e$, while those of $A O$ are of the $B 2$-type, 3 ) as to the relative population of the adrenoceptors, $C A$ is $B$-dominant $(\beta / \alpha 1=22)$, while $\mathrm{AO}$ is $\alpha 1$-dominant $(\beta / \alpha 1=0.07)$. The predominance of $\beta$-adrenoceptors and their relatively high affinity for $\mathrm{NE}$ (because they are of the Bl-type) may account for the weak contraction, or relaxation, of the $\mathrm{CA}$ induced by $\mathrm{NE}$, reported by other investigators in the experiments dealing with the responses of isolated coronary strips.

\section{$-128-$ \\ DUAL CONTROL OF MAXIMAL CORONARY VASODILATORY EFFECTS OF ADENOSINE BY ALPHA $_{2}$-ADRENOCEPTOR STIMULATION}

Masafumi Kitakaze, Masatsugu Hori, Yukihiro Koretsune, Jun Tamai, Kunimitsu Iwai, Katsuomi Iwakura, Masayoshi Mishima, Akira Kitabatake, Michihiko Tada, Michitoshi Inoue and Takenobu Kamada

The 1st Dept. of Med., Osaka Univ., Osaka

Potent alpha 2 -adrenoceptor stimulation elicits coronary vasoconstriction. To test the hypothesis that moderate alpha ${ }_{2}$-stimulation inversely augments the coronary vasodilatory effect of adenosine, 23 dogs were studied. The left anterior descending coronary arterial flow (CBF) was measured during maximal coronary vasodilation with adenosine under alpha ${ }^{-}$and alpha ${ }_{2}$-stimulation. To stimulate alpha ${ }_{1}$-adrenoceptors, norepinephrine (NE) was infused at the dose from $0.03 \mathrm{ug} / \mathrm{kg} / \mathrm{min}$ to $0.6_{\mu \mathrm{g}} / \mathrm{kg} / \mathrm{min}$ under pretreatments (PT) of prazosin and propranolol, and for alpha ${ }_{1}$-adrenoceptor stimulation same doses of $\mathrm{NE}$ were infused under PT of yohimbine and propranolol. Changes in CBF $(\mathrm{ml} / 100 \mathrm{~g} / \mathrm{min})$ during infusions of adenosine under alpha ${ }_{1}$ - and alpha ${ }_{2}$-stimulations were:

$$
\begin{array}{llll}
\text { UN PT Ado NE/0.24 } & 0.48 & 0.6
\end{array}
$$

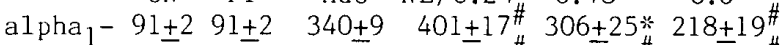
alpha $2-93 \pm 2 \quad 94 \pm 2 \quad 267 \pm 14 \quad 236 \pm 18^{\#} 208 \pm 18^{\#} 204 \pm 19^{\#}$ $\mathrm{UN}=$ untreated Ado=adenosine $\mathrm{NE}: \mu \mathrm{g} / 100 \mathrm{~g} / \mathrm{min}$ Mean $+\mathrm{SE}$ $* \mathrm{P}<0.05$ and $\# \mathrm{P}<0.01$ vs each value of $\mathrm{P}^{\prime} T$ with $\mathrm{Ad} 0$ Without adenosine infusion, NE decreased baseline CBF dose-dependently. On the other hand, moderate/potent alpha -attenuation reduced/augmented the maximal coronary blood flow. These results indicate that adenosine-induced maximal coronary vasodilation is still regulated by alpha ${ }^{-a d r e-}$ noceptor activity in a dual fashion: Moderate

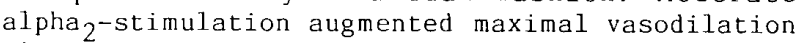
whereas potent alpha-stimulation reduced maximal vasodilation. This dual effect may play a pivotal role in the regulation of CBF during exercise or myocardial ischemia wherein the sympathetic activity and adenosine release are enhanced.

\section{$-129-$ \\ EFFECTS OF A NOVEL COMPOUND, Y-19638 HAVING ANTICHOLINERGIC AND CALCIUM BLOCKING ACTIONS ON ISOLATED HUMAN CORONARY ARTERY}

Isao Miyazawa, M.D., Ken-ichi Kawasaki, M.D., Tomoya Iino, M.D., Saichi Hosoda, M.D. and Jun Inui, Ph. D.*

Department of Cardiology, Jichi Medical School, Tochigi, Japan *Research Laboratories, Tokyo, Yoshitomi Pharmaceutical Industories

Methyl 3-diethylaminomethyl-7-methyl-5-(3-nitropheny 1) -5,8-dihydroimidazo[ $1,2-a]$ pyrimidine-6carboxylate hydrochloride $(Y-19638)$ is a newly synthetized compound having anticholinergic and calcium channel blocking effects. We evaluated the effects of this compound on the isolated human coronary artery in comparison with these of nitrendipine and atropine. The proximal portions 